\title{
Total Quality Management and Organizational Performance: A Possible Role of Organizational Culture
}

\author{
Faris Alghamdi ${ }^{1}$ \\ ${ }^{1}$ Faris Alghamdi, Business School, Albaha Univeristy, Albaha, SA \\ Correspondence: Faris Alghamdi, Business School, Albaha Univeristy, Albaha, SA.
}

Received: June 3, 2018

doi:10.5430/ijba.v9n4p186
Accepted: July 17, 2018

Online Published: July 23, 2018

\begin{abstract}
Total quality management (TQM) has been identified as a key driver of organizational performance in public and private organizations. Organizational culture, along with TQM, has investigated to understand its contributions to organizational performance. The purpose of this study is to examine the relationship between TQM and organizational performance, taking into account a moderating effect of organizational culture. A total of 163 managers at different managerial levels in public organizations in Albaha province participated. The Pearson correlation analysis revealed that the relationship between TQM and organizational performance is a positive and statistically significant. Hierarchical regression analysis and structural equation modeling (SEM) showed that the interaction of TQM and organizational culture was statistically significant and positively related to organizational performance. Some recommendations and suggestions for future research are provided.
\end{abstract}

Keywords: TQM, organizational performance, organizational culture, public organizations

\section{Introduction}

TQM is an integrated management philosophy that can be applied to public and private organizations. It facilitates a culture of continuous improvement through which successful organizations are striving to meet customers' perceptions of quality in order to boost customer satisfaction and an organizational performance. This can be proven by many awards such as the Malcolm Baldrige National Quality Award of the USA, Deming Prize in Japan, European Quality Prize, and King Abdul Aziz quality Award in the KSA. TQM includes a set of guiding principles and practices, focusing not only on the management of quality but also on the quality of management (Sadikoglu and Olcay, 2014; Pride and Ferrell, 2006; Brah et al., 2002).

The relationship between TQM and an organizational performance has been abundantly examined. However, while some studies suggested a significant impact ( Goetsch and Davis, 2006; Agus, 2005; Sanchez-rodriguez and Martinez-Lorente, 2004; Li et al., 2003; Yasin et al., 2004; Besterfield et al., 2003; Kaynak, 2003; Douglas and Judge, 2001), other studies did not suggest any (Brah et al., 2002; Sohal and Terziovski, 2000). Also, Soltani et al. (2005) claimed that the majority of UK organizations have not gained any tangible results from TQM.

Furthermore, the literature explained that only a third of TQM programs are successful, and the remaining ones fail largely due to a mismatch of cultural and structural variables (Gimenez-Espin et al., 2013). According to Kujala and Lillrank (2004) and Metri (2005), organizational culture is one of the most important variables in the success or failure of TQM program. It is believed that the prevailing organizational culture can support TQM by providing a more conducive environment that paves the way for success in the implementation of TQM (Baird et al., 2011). By the same token, organizational culture is considered an antecedent to TQM (Prajogo and McDermott, 2005). It is argued that culture change or at least culture awareness is an essential precondition for excellence and quality. However, it has been claimed that TQM implementation leads to changes in organizational culture (Jabnoun and Sedrani, 2005). In addition to that, Sousa-Poza et al. (2001) claimed that there is a reciprocal relationship between TQM and organizational culture. Having an adequate culture is needed for an effective TQM implementation. Likewise, some TQM programs such as training, employee involvement and empowerment do explicitly adjust culture.

The preceding discussion shows an inconsistency of results as to a relationship between TQM and organizational performance. It also shows mixed results in terms of an association between TQM and organizational culture. 
Moreover, there is a lack of examining these variables in the context of Saudi Arabia, Southern province. Hence, the current study addresses the impact of TQM on organizational performance in public organizations, Albaha province, taking into account a potential moderating effect of organizational culture (Alswidi and Mahmood, 2012; Abusa and Gibson, 2012; Ehigie and McAndrew, 2005). The next section will cover literature review, followed by methodology, data analysis, results, discussion, and conclusion.

\section{Literature Review}

\section{$2.1 T Q M$}

TQM has been defined in a variety of ways. It is a multidimensional concept that was a logical development of total quality control (TQC). Crosby (1979) defined quality as "conformance to requirements" (p. 17). Juran and Godfrey (1999) defined quality as "fitness for use" (p. 2). TQM is an integrated effort to attain and sustain a high-quality service based on the maintenance of continuous improvement of process and error prevention at all levels and in all functions of an organization, aiming to meet and even surpass customer needs and expectation (Gimenez-Espin et al., 2013).

TQM is assumed to be a culmination of a hierarchy of quality definitions: 1-quality-continuously satisfying customers' expectations, 2-total quality-achieving quality at low cost, and 3-TQM-achieving total through everyone participations (Dahlgaard et al., 2002). Ebrahimi and Sadeghi (2013) explained that the evolution of TQM to an all-pervasive management philosophy was formed by the works of Shewhart (1924), Deming (1982), Crosby (1979), Feigenbaum $(1951,1961)$, Ishikawa (1972), and Juran $(1986,1988)$. Their contributions (Table 1) have been very significant in the development of TQM and its application.

Table 1. Contributions of TQM's Gurus

\begin{tabular}{ll}
\hline Gurus & Contributions \\
\hline Shewhart (1924) & Control chart (CC) \\
Feigenbaum (1951, 1961) & Total quality control(TQC) \\
Ishikawa $(1976,1985)$ & Quality circles (QC) to achieve continuous improvement and fishbone \\
& diagram for problem-solving \\
Crosby $(1979)$ & Zero defects and 14 steps for quality improvement \\
Deming $(1982,1986)$ & Deming cycle (PDCA) and 14 principles to improve quality in \\
Juran (1986) & Three basic functions of the quality management process: \\
& quality planning, quality control, and quality improvement \\
\hline
\end{tabular}

Historically, TQM has been taken place in four stages: quality inspection, quality control, quality assurance, and TQM, respectively. The first stage was witnessed in the 1910s when the Ford Motor company's " $T$ " car began to hire a group of inspectors to test the product against the standard, covering the production process and delivery. The goal was to separate the poor product quality from the acceptable one, and hence scrapped, reworked or sold it as low quality. The second stage was from 1924 to 1931 when statistical quality control by inspection developed. Shewhart came up with the idea that quality control can aid in differentiating and isolating two kinds of process variation. The first one came from random causes, and the second came from assignable or special causes. He proposed that a process can be made to function predictably by sorting out the variation due to special causes. Additionally, he coins control chart for observing such process variation, therefore determining when to interact with the process. The third stage comprises all the former stages to provide sufficient confidence such that a product or service will satisfy customers' needs. This stage stressed on changing from detection to prevention of poor quality. The fourth stage, TQM, included the understanding and implementation of quality management's principles and concepts in every part of organizations. It demands that the principles of quality management have to be applied at every level, every stage, and in every department of the organization (Dahlgaard et al., 2002).

\subsection{Organizational Performance}

Organizational performance is a multidimensional construct that evaluates the position of an organization pertained to internal or external standards. Organizational performance and effectiveness are the most well-known concepts for evaluating organizations. The former concept is used for evaluating private organizations, and the latter is for evaluating public organizations. Yet, most of the organizational literature uses organizational performance to refer to the evaluation of private and public organizations (Clegg and Bailey, 2008). Moreover, the debate is taking place in 
the academic literature on some aspects of terminology, analysis level, and conceptual basis for assessment of organizational performance. It has been considered three different levels of performance within organizations: financial performance, business performance, and organizational performance (Montes et al., 2003; Chu-Hua et al., 2001).

Greenslade and Jimmieson (2007) explained that Borman and Motowidlo's performance theory suggests that the behaviors including the job performance domain can be classified into two types, namely, task and contextual performance. The task performance is a behavior that contributes directly to the organization's technical core, including those activities that are typically known as a part of a worker's job. Task performance behaviors are described based on role requirements and should be identified via a thorough job analysis. It is also referred to as inrole performance. On the other hand, contextual performance is defined as those behaviors that maintain the boarder social environment in which the technical core has to function. It includes workers' initiatives that lie outside the boundaries of formal job descriptions and are performed by workers at their own discretion. The behaviors that represent contextual performance are more stable across roles and contain organizational support, job-task support, and interpersonal support. Contextual performance is also referred to as extra-role performance (Bott et al., 2003; Coleman and Borman, 2000). It is asserted that public organizations have to focus on multiple dimensions of performance. Boyne (2002) proposed five conceptual categories: outputs, efficiency, effectiveness, responsiveness and democratic outcomes. Consequently, the current study applied effectiveness indicators, which refers to the achievement of formal goals, to measure organizational performance.

\subsection{Organizational Culture}

Organizational culture is a term that has proved extremely popular with management theories and managers alike. The term "culture" is theoretically rooted in social anthropology and was initially used in a holistic way to describe the qualities of a human group, passing from one generation to another (Karimi and Abdulkadir, 2012). It exists at different levels, including national culture and organizational culture. There has been no universal agreement on organizational culture construct. Yet, it is defined as the set of norms, values, beliefs, assumptions, and attitudes shared by organizational members, influencing behavior, performance outcomes, and the organizations' external environment (Gimenez-Espin et al., 2013; Alswidi and Mahmood, 2012; Helfrich et al., 2007). For the purpose of this study, the competing value framework (CVF) developed by Dension and Spreitzer (1991) is selected in order to classify types of organizational culture and their influence on study's variables. This framework is a widely accepted typology of organizational culture and has been used in several empirical studies (Gimenez-Espin et al., 2013; Zu et al., 2010; Stock et al., 2007; Lau and Ngo, 2004; Obenchain and Johnson, 2004). It is a combination of organizational theories and claims that most organizations can be characterized along two dimensions, each of which denotes alternative styles to basic challenges that all organizations have to deal with in order to function. The first dimension of the CVF is the degree to which an organization focuses on centralization and control over organizational processes as opposed to decentralization and flexibility. The second dimension is the degree to which an organization is oriented to its own inside environment and relationships with outside entities. Cross-classification of organizations on these two dimensions yields four prototypes, namely, hierarchical, rational, entrepreneurial, and team culture (Zu et al., 2010; Helfrich et al., 2007).

In this framework (Fig. 2.1), an organization that is an internally oriented and concentrates on control tags hierarchal culture or bureaucratic culture. It adopts clear lines of authority over organizational processes, considers formal hierarchy, and obeys rules, placing a priority on stability and predictability. An organization that is an internally oriented and concentrates on flexibility, tags team culture, boosts group participation of workers, and prompts teamwork and empowerment, placing a priority on human resource development. An organization that is an externally oriented and concentrates on flexibility, tags entrepreneurial culture, shows creativity and innovativeness, placing a priority on growth and expanding resources. An organization that is an externally oriented and concentrates on control, tags rational culture, favors clarity of goals and tasks, placing a priority on efficiency and measurable outcomes. Organizations, to some extent, reflect all four cultures. The CVF framework does not favor one culture over the other. Nevertheless, an essential assumption of the CVF is that all four cultures operate at organizational levels and they are relatively stable over time. Some organizations reveal only one culture type which is more dominant and other organizations show a combination of different culture types ( $\mathrm{Zu}$ et al., 2010; Helfrich et al., 2007; Henri, 2006; Prajogo and McDermott, 2005). 


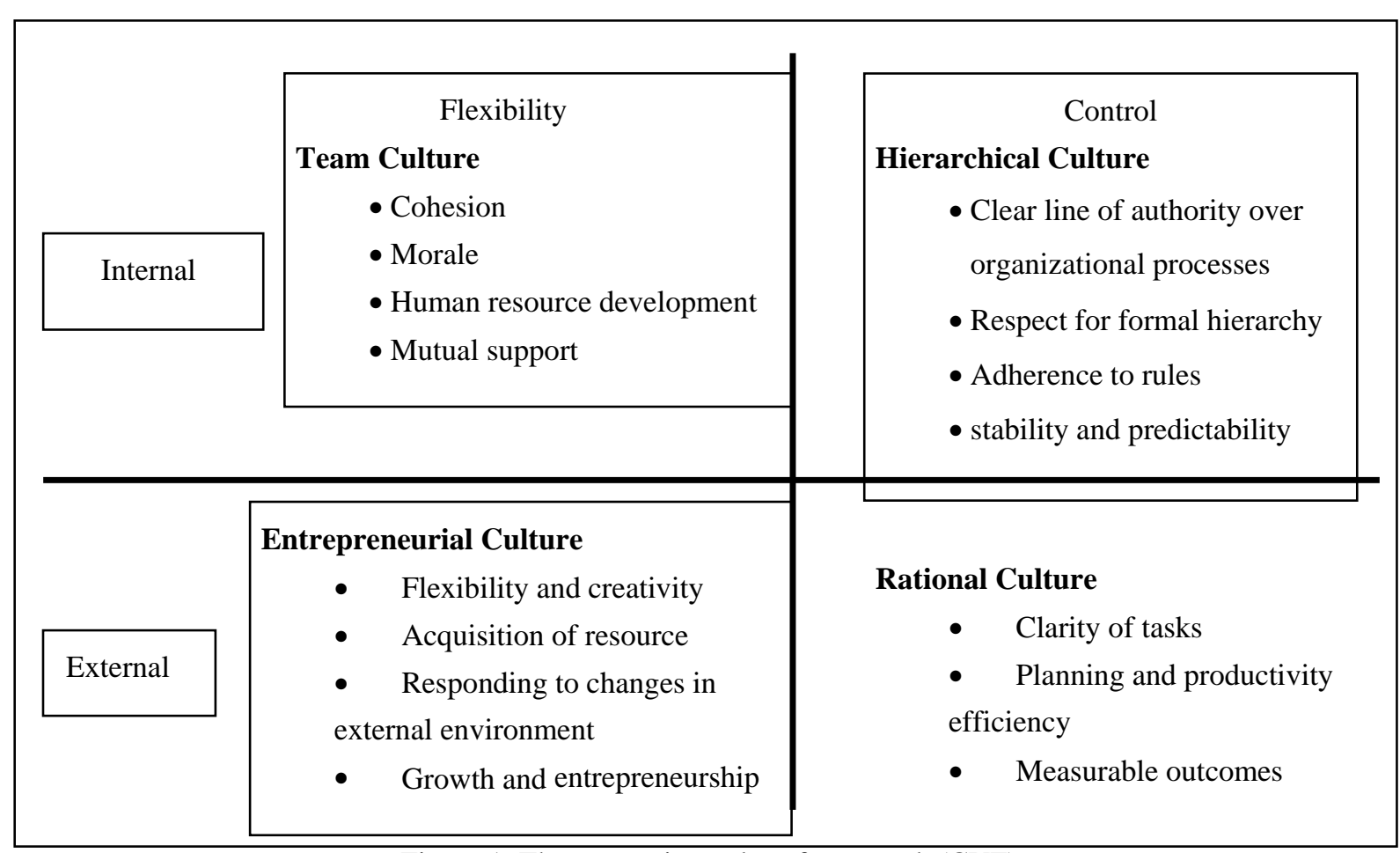

Figure 1. The competing values framework (CVF)

Adapted from: Helfrich, C. D., Li, Y., C Mohr, D., Meterko, M., and Sales, A. E. (2007) "assessing an organizational culture instrument based on the competing values framework: exploratory and confirmatory factor analyses." Implementation Science, 2, 1-14.

\subsection{TQM and Organizational Performance}

The relationship between TQM and organizational performance has been extensively examined, yet mixed results have been reported. Most of the previous studies concluded a positive relationship between TQM and organizational performance. Rahman and Bullock (2005) studied 261 Australian manufacturing companies and concluded the elements of soft TQM (i.e., workforce commitment, shared vision, customer focus, use of teams, and cooperative supplier relations) were significantly related to the measures of organizational performance. Moreover, the elements of hard TQM (i.e., use of JIT principles, technology utilization, and continuous improvement enablers) were significantly related to the measures of organizational performance. A study was undertaken in Turkey to investigate the impact of TQM practices on various performances measures. The study revealed that TQM was significantly and positively related to performance. Additionally, TQM practices, in general, improve organizational performance (Sadikoglu and Olcay, 2014). Another study was done to examine the extent of TQM practices implemented in Palestinian hospitals and their relationship to organizational performance using the Malcolm Baldrige National Quality Award Criteria. The results of the study showed that TQM constructs i.e., MBNQA were positively related to hospital performance, and for the most part the relationship was significant (Sabella et al., 2014).

Moreover, a study was conducted in UAE to investigate, in part the correlation between TQM and organizational performance. The study concluded that TQM's principles (i.e., customer focus and continuous improvement) had the highest correlation coefficient with organizational performance (Jabnoun and Sedrani, 2005). However, few studies reported different results. For example, an empirical study was conducted, selecting a sample from both manufacturing and nonmanufacturing sectors. The study aimed to examine the relationship between TQM practice and quality performance in Australian organizations. The findings suggested that TQM program did not entirely impact quality performance. The study concluded that TQM program did not improve the relationship between TQM practice and quality performance (Prajogo and Brown, 2004). It is asserted that an organization with a high level of top management commitment generates a high-quality outcome. Management leadership, training, and employee relations have an indirect influence on performance (Kaynak, 2003). Customer involvement as one of TQM elements in this study, influences organizational performance in improving initial design quality and permitting determination of critical specifications and tolerances, which, in turn, resulting in the design of new features that meets their 
expectations. Hence, an organization with a high level of customer satisfaction and loyalty is more likely to have a high level of organizational performance (Flynn et al., 1995). From the discussion above, the first hypothesis is proposed:

$\mathrm{H} 1$ : There is a significant positive relationship between TQM practice and organizational performance.

\subsection{A Possible Role of Organizational Culture}

Many studies have been conducted to examine the possible role of organizational culture in the relationship between TQM and organizational performance. TQM had a significant positive impact on organizational performance. The interaction between organizational culture and TQM was negative and statistically significant (Al-Swidi and Mahmood, 2012). TQM practices had a statistically significant impact on the organizational performance. Furthermore, the study confirmed combined effects of organizational culture and TQM practices on organizational performance (Jabnoun and Sedrani, 2005). From the practical perspective, some of the total quality management implementation failures have mentioned in the literature. A number of studies reported failure rates as high as $60-70 \%$. Hence, one possible reason for that failure is the lack of realizing the role of organizational culture (Naor $e t$ al., 2008; Beer, 2003; Shin et al., 1998). Organizational culture, i.e., the entrepreneurial culture encourages employees to suggest new ideas and take risks as a part of a process of continues improvement, which is a major component of TQM (Dean and Bowen, 1994). Organizational culture, i.e., team culture is pertaining to TQM in terms of empowerment, open communication (Evans and Lindsay, 2002). It is claimed that specifying ambitious, yet attainable goals is essential to the success of TQM programs (Linderman et al., 2003). Finally, cultural values impact organizational performance indirectly by their influence on cultural tasks and attitudes (Naor et al., 2008). Based on the above discussion, the following hypothesis is proposed:

$\mathrm{H} 2$ : Organizational culture moderates the relationship between TQM and organizational performance.

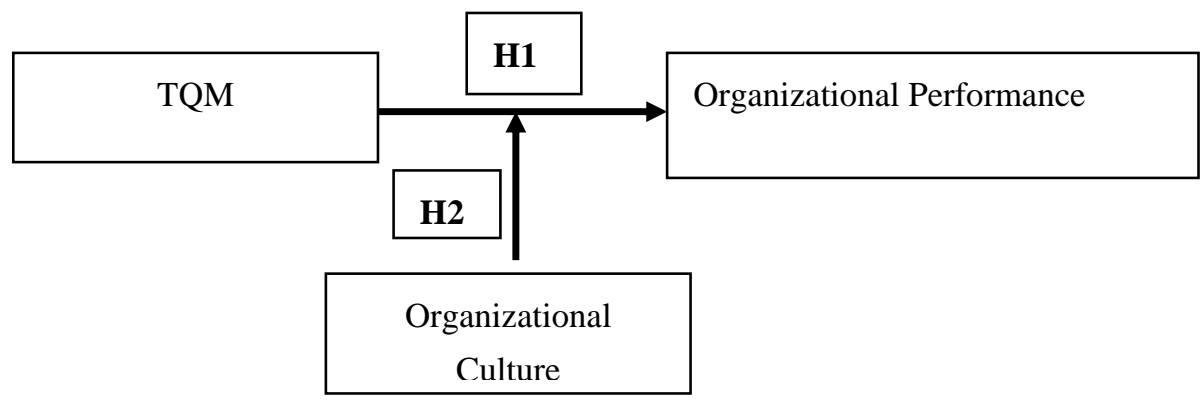

Figure 2. Research model

\section{Methodology}

\subsection{Instrument}

The current study applied a descriptive cross-sectional method. The study instrument includes three main variables that were measured. TQM comprises three dimensions, human resource focus, customer focus, and top management commitment. The first dimension was measured using 7-items provided by Sabella et al. (2014). The second dimension was measured using 5-items provided by Sadikoglu and Olcay (2014). The last dimension was measured using 3-items coined by Powell (1995). It is noteworthy to mention that these three dimensions were carefully selected based on an annotated review done by Ebrahimi and Sadeghi (2013). A comprehensive review of quality management literature showed more than 200 quality management practices, and therefore only seven practices of these were repeatedly reported. The first three most important practices for the success of quality management were human resource management, customer focus, and top management commitment, respectively. Moreover, these three dimensions are consistent with the first three dimensions of Baldrige model, namely, leadership, constituents, and workforce focus (Immordino, 2010).

The second study variable is organizational performance that measured using 4-items provided by Sadikoglu and Olcay (2014). The last main variable is organizational culture that measured using the competing values framework CVF. The CVF includes four types of organizational culture. The first type is entrepreneurial culture that measured using by 4-items, the second type is hierarchical culture that measured using 4-items, the third type is team culture that measured using 3-items, and the last type is rational culture that measured using 3-items (Helfrich et al., 2007). 
The response was recorded on a five-point scale wherein " 1 " indicates "strongly disagree" and "5" indicates "strongly agree". The modified questionnaire was translated from the English language to the Arabic language, which is the official language for all potential participants, using a back-translation technique. In doing so, a professor at Albaha University translated the modified questionnaire into Arabic language and then another professor at the same university translated back to the English language without references to the original English version. Both professors are fully bilingual. After that, the researcher went carefully over both versions and made revisions needed in order to ensure a complete and accurate meaning of the original text of the modified questionnaire. Also, the researcher wanted to ensure that an appropriate level of formality for all potential participants is achieved.

\subsection{Sample}

The target population of this study consisted of employees in Albaha province, Saudi Arabia, working in nine public organizations. The unit of analysis was all employees at different managerial levels. As for confidentiality for all participants, the protocol-describes the means whereby personal information is collected, kept secure, and maintained-was explained clearly, including anonymity of all participants. A cover letter providing some information about the importance of the study, participants' rights, as well as explaining how to respond to the questionnaire items was attached. The sample of the study was selected using the convenience sampling technique. There were 240 self-administered questionnaires distributed to participants who met the criteria mentioned above. Trained employees worked with the researcher have been assigned to distribute the questionnaires to potential subjects and then collect all questionnaires that have been filled. From that, 163 were returned and useful for analysis, with a response rate of $68 \%$.

\section{Data Analysis}

Descriptive statistics were used to summarize data. To confirm the model fit, confirmatory factor analysis was performed; and the internal consistency reliability was estimated by Cronbach's alpha. The current study utilized Pearson correlation to examine the relationship between TQM practices and organizational performance. Hierarchical regression analysis and Structural equation modeling were used to examine the hypothesized moderation relationship in the line with Baron and Kenny (1986). The study used SPSS for Windows 22 and AMOS 21 software to summarize study data and to examine the first and second hypothesizes, as well as internal consistency reliability. Moreover, at the stage of confirmatory factor analysis (CFA), AMOS 21 software was used to reach an optimal model. Statistical significance at $P<0.01$ and $P<0.05$ was used to examine study's hypotheses.

\section{Results}

Table 3 depicts the demographic data of participants. The majority of the participants were male $(52.8 \%)$. The age ranged from 29 to 39 had the majority of the participants (50.3\%). The undergraduate participants were the majority of other categories (69.9\%). As for work experience, participants with work experience ranged from 5 to 15 years had the highest percentage of participants $(36.2 \%)$. Of the sample, the majority of the participants were middle-level managers (54\%).

Moreover, there were two direct questions regarding TQM, the first of which was asking participants if they have had, during their past experience, any training courses in TQM and its applications. Of the sample, $50.9 \%$ have had at least one training course in TQM and its applications and $49.1 \%$ have not had any. Another question was asking participants if the organizations they work for have implemented TQM or other related programs. The majority of the participants said yes (63.8\%) and the remaining said no (36.2\%). The study applied a first and second-order confirmatory factor analysis to reach an optimal model fit. First, the second order CFA was used for the TQM construct. The second- order three factors model demonstrates acceptable fit statistics: CMIN/DF $=1.4, \mathrm{CFI}=0.97$, SRMR $=0.03$ and RMSEA $=0.05$ (Hair et al., 2014). The three first-order factors loaded significantly onto the second order factor, factor loadings ranged from 0.91 to 0.93 . 
Table 2. Demographic data of participants

\begin{tabular}{lcc}
\hline \multicolumn{1}{c}{ Variable } & $\begin{array}{c}\text { Frequency } \\
\text { N= } 163\end{array}$ & Percentage (\%) \\
\hline Gender & & \\
Male & 86 & 52.8 \\
Female & 77 & 47.2 \\
Age & & \\
$18-28$ & 16 & 9.8 \\
$29-39$ & 82 & 50.3 \\
40-50 & 54 & 33.1 \\
51- and above & 11 & 6.7 \\
Level of Education & & \\
Before high school & 1 & 0.6 \\
High school & 13 & 8.0 \\
Undergraduate & 114 & 69.9 \\
Graduate & 35 & 21.5 \\
Work Experience & & \\
Less than 5 years & 32 & 19.6 \\
5-15 & 59 & 36.2 \\
16-26 & 52 & 12.3 \\
27 or more & 20 & \\
Managerial Level & & 26.4 \\
Top management & 43 & 54.0 \\
Middle management & 88 & 16.9 \\
Lower management & 32 & \\
\hline
\end{tabular}

Moreover, all items in the scale had factor loading in excess of 0.73 . The results from first and second-order confirmatory factor analysis for the whole sample $(n=163)$ are displayed in Figure 3. Construct validity was supported via a second-order three-factor model with acceptable goodness-of-fit indices (Hochwälder and Brucefors, 2005). It should be noted that the model was modified to reach an optimal one. First, item 6 was deleted since its load was below the threshold of 0.4. Second, based on modification indexes, because the correlation between a pair of measurement error, that is, e 11 and e 12 was greater than 15 , the modification to the measurement model was made.

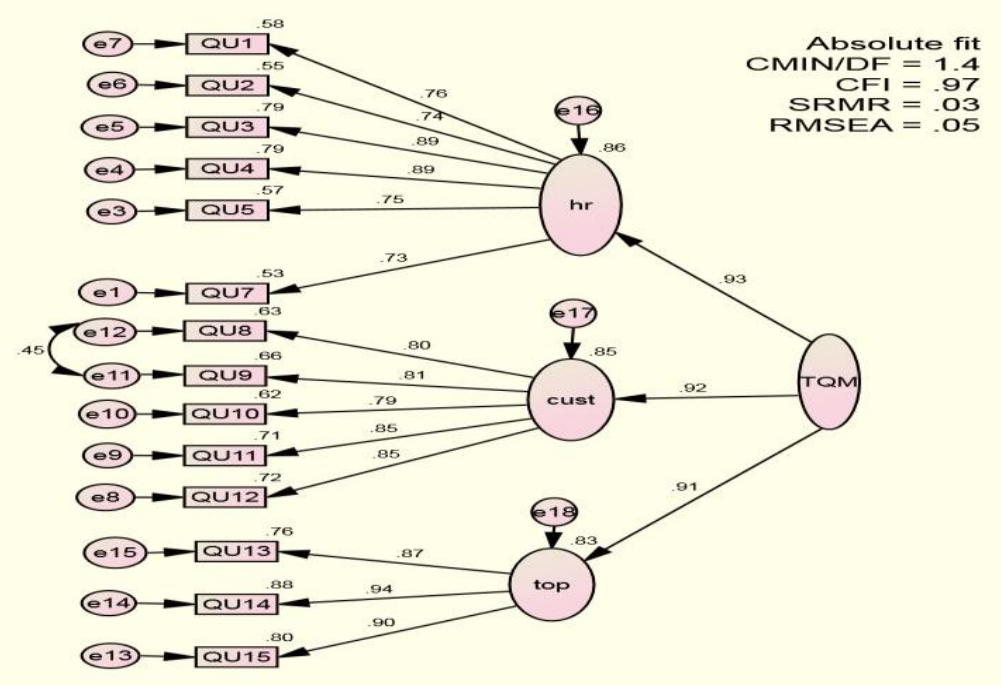

Figure 3. TQM scale second-order CFA indicating three first-order factors loading onto a signal second-order TQM factor 
Second, for organizational performance construct, the first-order one factor model demonstrates acceptable fit statistics: $\mathrm{CMIN} / \mathrm{DF}=1.3, \mathrm{CFI}=0.99, \mathrm{SRMR}=0.02$ and RMSEA $=0.04$ (Hair et al., 2014). All items on the scale had factor loading in excess of 0.42 . The results from first order confirmatory factor analysis for the whole sample $(n=163)$ are displayed in Figure 4. It should be noted that the model was not modified whatsoever.

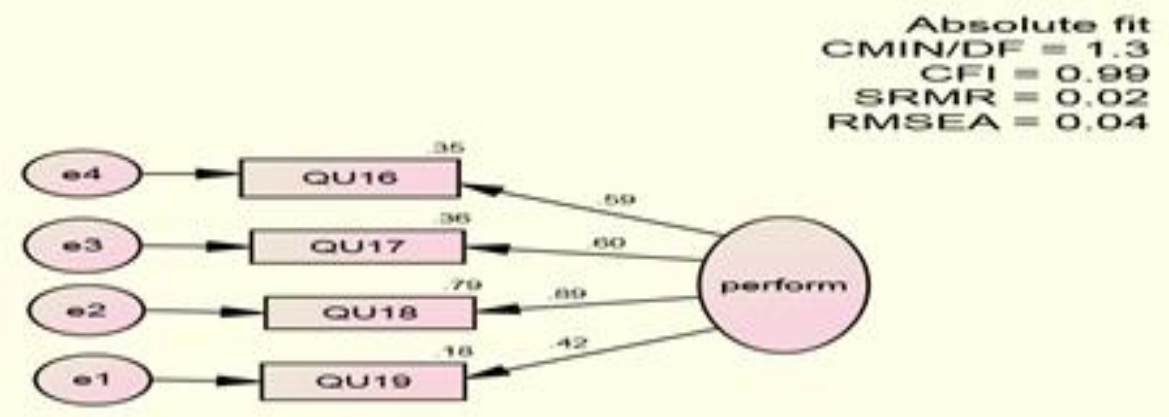

Figure 4. Organizational performance scale first-order CFA indicating one first-order organizational performance factor

Third, for the organizational culture construct, the second- order four factors model demonstrates acceptable fit statistics: $\mathrm{CMIN} / \mathrm{DF}=1.5, \mathrm{CFI}=0.98, \mathrm{SRMR}=0.04$ and RMSEA $=0.05$ (Hair et al., 2014). The four first-order factors loaded significantly onto the second order factor, factor loadings ranged from 0.66 to 1 . Moreover, all items in the scale had factor loading in excess of 0.53 . The results from first and second-order confirmatory factor analysis for the whole sample $(n=163)$ are displayed in Figure 5. Construct validity was supported via a second- order four-factor model with acceptable goodness-of-fit indices (Hochwälder and Brucefors, 2005). It should be noted that the model was modified to reach an optimal one. First, item 24 was deleted since its load was below the threshold of 0.4. Second, based on modification indexes, because the correlation between a pair of measurement error, that is, e8 and 99 was greater than 8 , the modification to the measurement model was made.

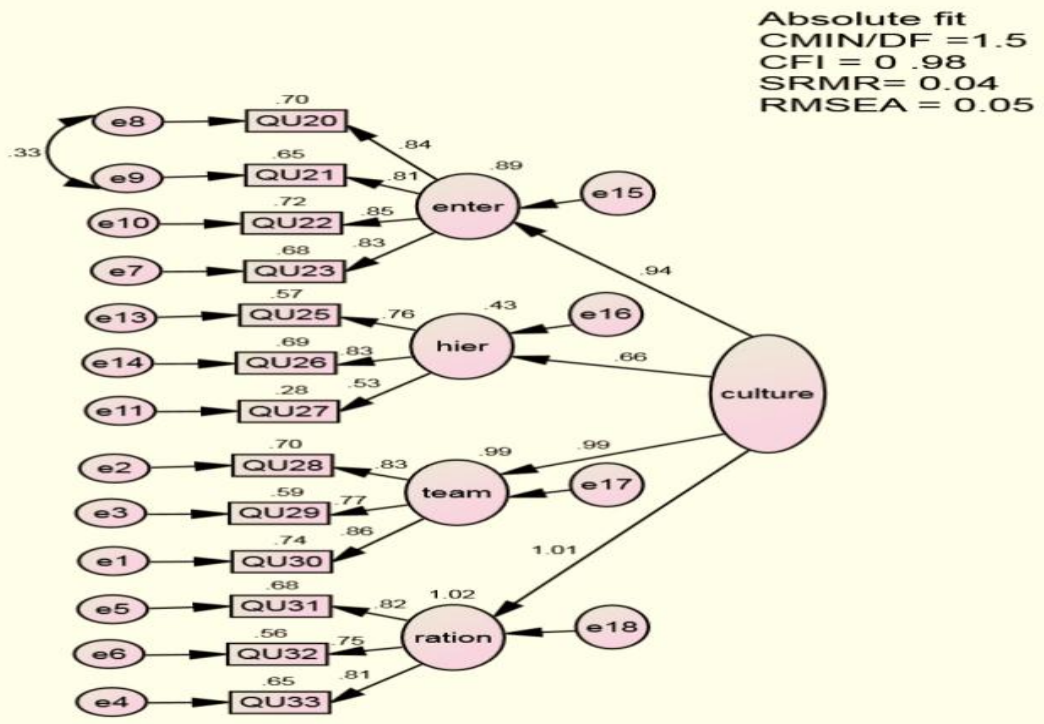

Figure 5. Organizational culture scale second-order CFA indicating four first-order factors loading onto a signal second-order organizational culture factor 
Finally, internal consistency coefficient for each construct was assessed using Cronbach' alpha coefficient. The TQM construct encompasses 14-items and Cronbach' alpha was 0.95 , the organizational performance comprises 4 items and Cronbach' alpha was 0.72 , and the organizational culture includes 13 items and Cronbach' alpha was 0.93. Therefore, the internal consistency reliability coefficient for the TQM construct and for the organizational culture deems high, whereas the internal consistency reliability coefficient for the organizational performance deems acceptable (Nunnaly, 1978). For the first study hypothesis, Pearson correlation analysis was used to examine the relationship between the TQM practice and the organizational performance. The first study hypothesis stated that there is a significant positive relationship between TQM practice and organizational performance. The results from Pearson correlation analysis for the whole sample $(n=163)$ are displayed in table 3 . As shown, the relationship between the TQM and the organizational performance is a positive and statistically significant $(p<0.01)$. A strong positive correlation was found between the TQM and the organizational performance $(r=0.74)$. Hence, the first study hypothesis was supported.

Table 3. Relationship between TQM and OP

\begin{tabular}{cccc}
\hline & & TQM & PERF \\
\hline TQM & Pearson Correlation & 1 & $.744^{* *}$ \\
& Sig. (2-tailed) & & .000 \\
$\mathrm{~N}$ & 163 & 163 \\
PERF & Pearson Correlation & $.744^{* *}$ & 1 \\
& Sig. (2-tailed) & .000 & \\
& $\mathrm{~N}$ & 163 & 163 \\
\hline
\end{tabular}

**. Correlation is significant at the 0.01 level (1-tailed).

For the second study hypothesis, hierarchical regression analysis was used to examine the hypothesized moderation relationship in the line with Baron and Kenny (1986). In formulating the regression equation, standardizing predictor and moderator variables were undertaken prior to multiplication. This step was done in order to eliminate the problems of non-essential multicollinearity between two independent variables, $\mathrm{X}$ and $\mathrm{M}$, with the product term $\mathrm{X} * \mathrm{M}$ (WU and Zumbo, 2008). The regression analysis was performed in 4 steps. That is, the control variables were entered in step 1, the TQM in step 2, organizational culture in step 3, and the interactive term (TQM * CULT) in step 4 in predicting the organizational performance. The second study hypothesis stated that the organizational culture moderates the relationship between the TQM and the organizational performance. The results from hierarchical regression analysis and structural equation modeling for the whole sample $(\mathrm{n}=163)$ are displayed in Table 4 and Fig.6. The interaction of the TQM and the organizational culture was statistically significant and positively related to the organizational performance $(\beta=0.121, P<0.05)$. Moreover, there was a significant increment in $R 2$ of the model $(\Delta R 2=.0 .010), P<0.05)$. Therefore, the second study hypothesis was supported. 
Table 4. Hierarchical regression: Assessing moderating effects of organizational culture

Dependent variable and standardized regression weights

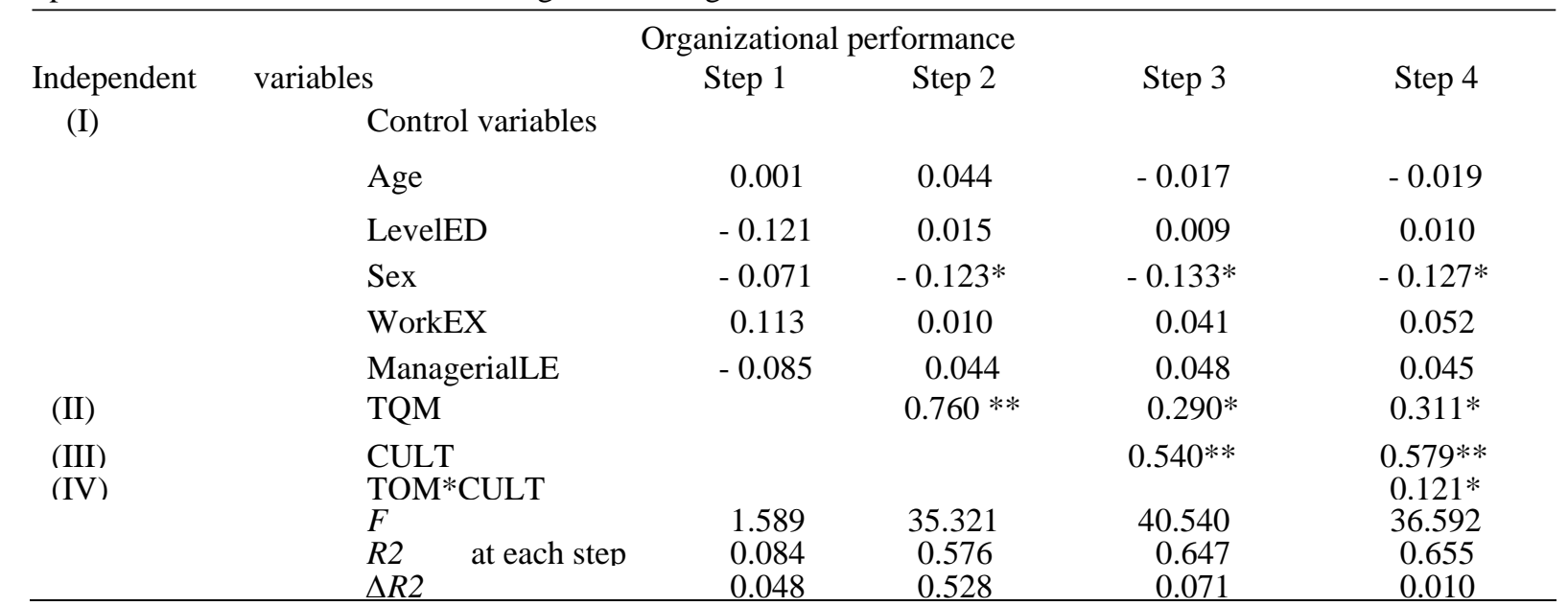

Note: LevelED = level of education; workEX = work experience; managerialLE = managerial level; TQM = total quality management; CULT = organizational culture. The results of variance inflation factor (VIF) did not show any problems of multicollinearity.

$* P<05 ; * * P<01$

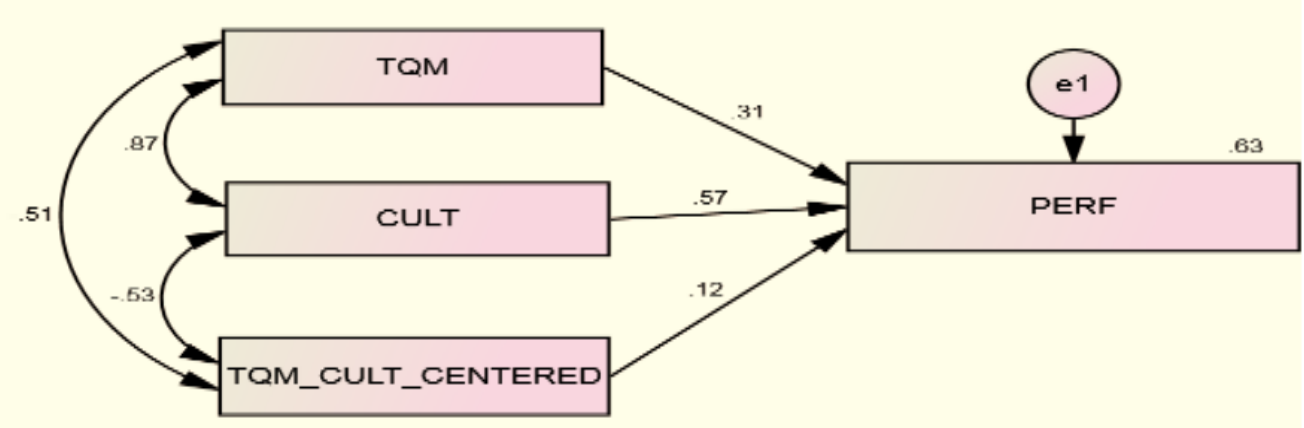

Figure 6. Structural equation modeling: Assessing moderating effects of organizational culture

The moderating effect of the organizational culture on the relationship between the TQM and the organizational performance is illustrated graphically in (Fig. 7). That is, there was a positive impact of the TQM on the organizational performance to be stronger for public organizations with a higher level of organizational culture. It is concluded that the organizational culture strengthens the positive impact of the TQM on the organizational performance. 


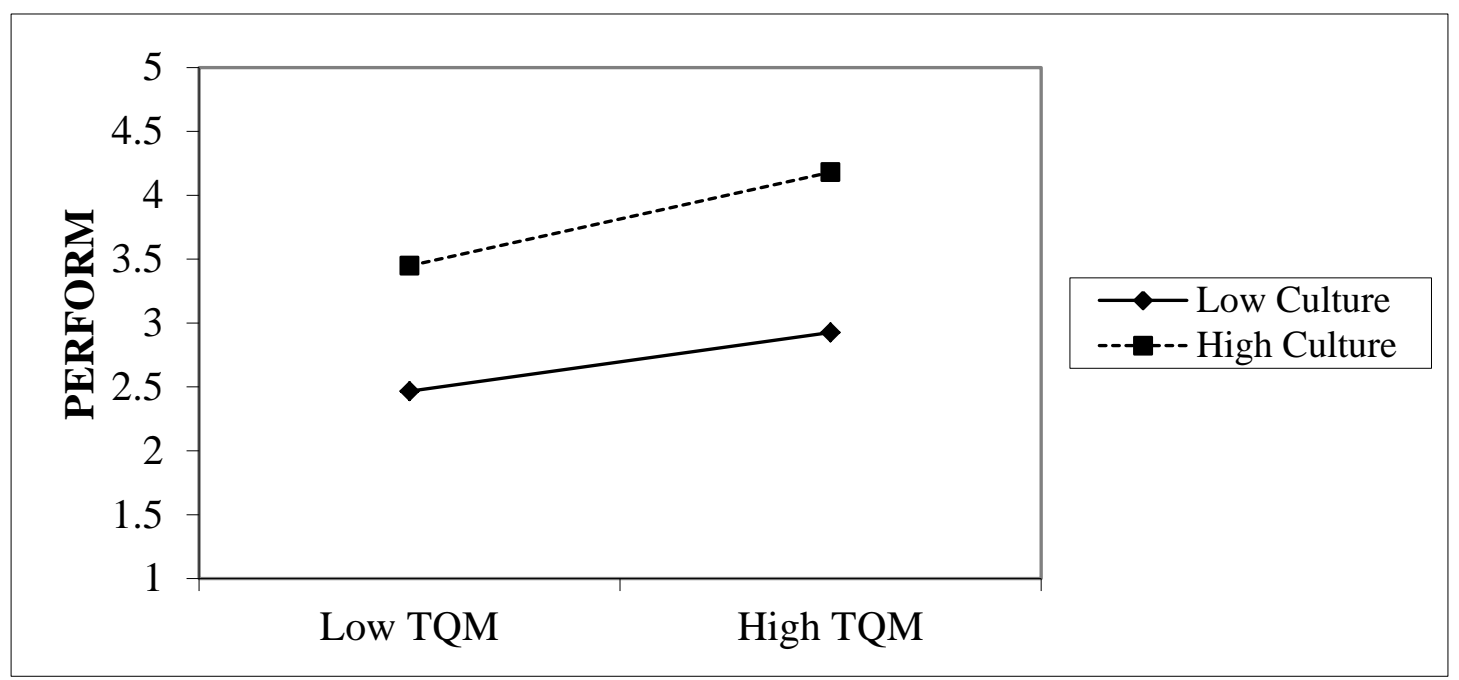

Figure 7. Moderating effect of CULT on TQM and PERFORM's relationship

The findings of the current study support most of the previous studies regarding the important role of organizational culture in improving organizational performance, linking to effective TQM program implementation. As shown, a strong positive relationship between the TQM and the organizational performance was found. The more effective TQM program is implemented, the higher the organizational performance will be reported. Within this context, what we mean by more effective TQM program is the program that has a high level of TQM implemented in public organizations in Albaha province with a high level of organizational culture (i.e., hierarchical and rational cultures). It also had a stronger and statistically significant association with a high TQM than entrepreneurial and team cultures. Similarly, a high TQM (i.e., human resource management) had a stronger and statistically significant association with a high level of organizational culture than a low TQM (i.e., top management and customer focus). In general, these results are in line with previous studies (e.g., Valmohammadi and Roshanzamir, 2014; Sadikoglu and Olcay, 2014; Gimenez-Espin et al., 2013; Alswidi and Mahmood, 2012; Jabnoun and Sedrani, 2005; Prajogo et al., 2005; Prajogo and Brown, 2004; Brah et al., 2002).

The study's results suggested that the hierarchical $(\mathrm{M}=3.72 \mathrm{SD}=0.8)$ and rational $(\mathrm{M}=3.65, \mathrm{SD}=0.87)$ cultures are more dominant types of organizational culture in public organizations in Albaha province. These organizations focus on adherence to rules and stability more than flexibility and creativity. They are considered effective if they are stable, predictable, and mechanistic. It should be noted that this kind of cultural profile becomes the standard, in a way that team and entrepreneurial cultures are being diminished and the hierarchical and rational cultures are being focused on (Valmohammadi and Roshanzamir, 2014; Cameron and Quinn, 2005). It is believed that the existence of hierarchical culture in a non-western culture is not surprised since Saudi Arabia is regarded as having a high power distance on Hofstede's power distance Index. This means that Saudi's organizations admit their place and realize the existence of formal hierarchical positions (Hofstede, 2011). Likewise, having rational culture that focuses on achieving defined goals and outcomes is common. Saudi Arabia is a developing country in which traditional management prevails. This kind of management emphasizes more on effectiveness than efficiency, in which mangers focus on ends, not on means. This may jeopardize the efficient use of organization resources, in favor of achieving organizational objectives. The father of modern management, Peter Drucker, stresses the fact that an equal focus on effectiveness and efficiency is crucial for modern organizations (Morrill, 2008).

Finally, the current study applied the soft elements of the TQM, that is, top management commitment, human resource management, and customer focus. A stronger and statistically significant association found between customer focus and organizational performance $(p<0.01 ; \mathrm{r}=0.71)$. This finding confirmed the earlier studies that special attention must be paid to organizational customers in order to increase organizational performance. That includes close contact with them, seeking their inputs to identify needs and expectations, which should be conveyed to organizations' employees, and using their complaints to improve quality and delivery performance (Sadikoglu and Olcay, 2014, Zu et al., 2008; Sila, 2007; Das et al., 2000). 
In addition, a stronger and statistically significant association found between team culture and organizational performance $(\mathrm{p}<0.01 ; \mathrm{r}=0.76)$. It is not surprising that working together as a team to generate particular performance goals aids shifting teams from working individually into committed groups that contribute to improving organizational performance (Alrawi, 2008). This finding is supported by other studies that focus on the impact of team culture on organizational performance. They paid attention to managers' personality, developing employees, full potential, high commitment to organizations, loyalty and tradition that gluing an organization together, and focusing on HR, high cohesion and morale (Alhwairini and Foley, 2012; Karimi and Abdulkadir, 2012; Baird et al., 2011; Alswidi and Mahmood, 2011; Zu et al., 2009; Helfrich et al., 2007).

\section{Conclusion}

Total quality management is an integrative organizational- wide philosophy, by which an organization can augment competitiveness, enhancing products, services, and processes, diminishing cost, and improving organizational performance. The current study confirmed this explanation in term of the relationship between the TQM and organizational performance. It is evidence that the association between these variables were strongly positive and statistically significant. Hence, managers of public organizations in Albaha province should turn attention towards activating the role of the TQM, with more focus on customers, human resource, and top management commitment. Certainly, in the presence of top management commitment, this would help public organizations, in the long run, improving their performance and responding to internal and external customers' needs and expectations effectively and efficiently.

Organizational culture, i.e., competing values framework, when was added to the TQM variable to see the interaction effect, it showed that the organizational culture contributed to the effect of the TQM on organizational performance. That is, organizational culture strengthens the positive impact of the TQM on organizational performance. Managers in public organizations in Albaha province is recommended that the TQM would not completely benefit organizations unless an appropriate organizational culture exists. The TQM alone is not enough to optimize organizational performance and hence achieving organizations' goals and objectives. It is very important for managers to recognize the premise of contingency theory that a type of cultures must fit an organizational strategy to ensure the successful implementation of the TQM. This can be done through collective efforts of all team members assigned to study an organization and its internal and external environment in order to help implement a new and successful management philosophy, i.e., the TQM.

The current study, in spite of the large-scale, suffers from limitations, and hence contributing to some suggestions for future research. Researchers who are interested in studying organizational management should concentrate on comparative research design. This can help to understand the difference between public and private sectors in terms of these three variables and their relationships, as well as among different regions of Saudi Arabia. This can give a better understanding of the TQM and its implementation in a non-western culture and the factors that may help or hinder these processes. It is also recommended that researchers can examine a different kind of performance besides organizational performance, that is, extra-role performance or contextual performance to learn more about the TQM and organizational cultures' role in enhancing such performance. Finally, due to the lack of information regarding the sampling frame from Saudi authority and time constraints, the current study applied a non-probability sampling technique, i.e., convenience sampling. Thus, researchers are recommended to use a random sampling technique so that issues regarding external validity can be eliminated.

\section{Acknowledgment}

This research is a part of a project entitled "Total quality management and organizational performance: a possible role of organizational culture". This project was funded by the Deanship of Scientific Research, Albaha University, KSA (Grant No. 06-1437). The assistance of the Deanship is gratefully acknowledged

\section{References}

Abusa, F., \& Gibson, P. (2013), Experiences of TQM elements on organizational performance and future opportunities for a developing country. International Journal of Quality \& Reliability Management, 30(9), 920-941. https://doi.org/10.1108/IJQRM-07-2012-0106

Agus, A. (2005). The structural linkages between TQM, product quality performance, and business performance: a Preliminary empirical study in electronics companies. Singapore Management Review, 27(1), 87-105.

Alhaqbani, A. (2013). Impact of key organizational factors in facilitating TQM in a Saudi Arabian public sector organization: An empirical study. International Journal of Innovations in Business, 2(8), 732-761. 
Alhwairini, A., \& Foley, A. (2012). Working towards total quality management in Saudi Arabia. Education, Business \& Society Education, Business, and Society: Contemporary Middle Eastern Issues, 5(3), 187-199. https://doi.org/10.1108/17537981211265570

Alrawi, K.W. (2008). Knowledge management and organization's perception in the United ArabEmirates: case study. International Journal of Commerce and Management, 18(4), 382-394. https://doi.org/10.1108/10569210810921988

Alswidi, A., \& Mahmood, R. (2012). Total quality management, entrepreneurial orientation and organizational performance: the role of organizational culture. African Journal of Business Management, 6(13), 4717-4727.

Baird, K., Hu, K., \& Reeve, R. (2011). The relationships between organizational culture, total quality management practices and operational performance. International of Operation \& Production Management, 31(7), 789-814. https://doi.org/10.1108/01443571111144850

Baron, R.M., \& Kenny, D.A. (1986). The moderator-mediator variable distinction in social psychological research: Conceptual, strategic, and statistical considerations. Journal of Personality and Social Psychology, 51(6), 1173-1182. https://doi.org/10.1037/0022-3514.51.6.1173

Beer, M. (2003). Why total quality management programs do not persist: the role of management quality and implications for leading a TQM transformation. Decision Sciences, 34(4), 623-642. https://doi.org/10.1111/j.1540-5414.2003.02640.x

Besterfield, H.D., Besterfield-Michna, C., Besterfield, G.H., \& Besterfield-Sacre, M. (2003). Total quality management. New Jersey: Prentice Hall.

Bott, J.P., Svyantek, D.J., Goodman, S.A., \& Bernal, D.S. (2003). Expanding the performance domain: who says nice guys finish last?. International Journal of Organizational Analysis, 11(2), 137-152. https://doi.org/10.1108/eb028967

Boyne, G., Day, P., \& Walker, R. (2002). The evaluation of public service inspection: a theoretical framework. Urban Studies, 39(7), 1197-1212. https://doi.org/10.1080/00420980220135563

Brah, S.A., Tee, S.S., \& Rao, B.M. (2002). Relationship between TQM and performance of Singapore companies. International Journal of Quality \& Reliability Management, 19(4), 356-379. https://doi.org/10.1108/02656710210421553

Cameron, K.S., \& Quinn, R.E. (2005). Diagnosing and changing the organizational culture: Based on the competing values framework. Reading, MA: Addison-Wesley.

Chu-Hua, K., Madu, C.N. \& Lin, C. (2001). The relationship between supply chain quality management practices and organizational performance. International Journal of Quality\& Reliability Management, 18(8), 864-872. https://doi.org/10.1108/EUM0000000006031

Clegg, S.R., \& Bailey, J. (2008). International Encyclopedia of Organization Studies. Thousand Oaks, CA: Sage. https://doi.org/10.4135/9781412956246

Coleman, V.I., \& Borman, W.C. (2000). Investigating the underlying structure of the citizenship performance domain. Human Resource Management Review, 10(1), 25-44. https://doi.org/10.1016/S1053-4822(99)00037-6

Crosby, P. (1979). Quality is free: The art of making quality certain. New York: McGraw-Hill.

Dahlgaard, J.J., Kristensen, K., \& Kanji, G.K. (2002). Fundamentals of Total Quality Management. London: Nelson Thornes.

Das, A., Handfield, R.B., Calantone, R.J., \& Ghosh, S. (2000). A Contingent View of QualityManagement-The Impact of International Competition on Quality. Decision Sciences, 31(3), 649-690. https://doi.org/10.1111/j.1540-5915.2000.tb00938.x

Dean, J.W., \& Bowen, D.E. (1994). Management theory and total quality: improving research and practice through theory development. Academy of management review, 19(3), 392-418. https://doi.org/10.5465/amr.1994.9412271803

Douglas, T.J., \& Judge, W.Q. (2001). Total quality management implementation and competitive advantage: the role of structural control and exploration. Academy of Management Journal, 44(1), 158-169.

Ebrahimi, M., \& Sadeghi, M. (2013). Quality management and performance: An annotated review. International Journal of Production Research, 51(18), 5625-5643. https://doi.org/10.1080/00207543.2013.793426 
Ehigie, B.O., \& McAndrew, E.B. (2005). Innovation, diffusion and adoption of total quality management. Management Decision, 43(6), 925-940. https://doi.org/10.1108/00251740510603646

Evans, J.R., \& Lindsay, W.M. (2002). The management and control of quality.Cincinnati, OH: South-Western.

Flynn, B.B., Schroeder, R.G., \& Sakakibara, S. (1995). The impact of quality management practices on performance and competitive advantage. Decision $\quad$ Sciences, https://doi.org/10.1111/j.1540-5915.1995.tb01445.x

Gimenez-Espin, J.A., Jiménez-Jiménez, D., \& Martínez-Costa, M. (2013). Organizational culture for total quality management. Total Quality Management \& Business Excellence, 24(5-6), 678-692. https://doi.org/10.1080/14783363.2012.707409

Glunk, U. (2008). Organizational Performance. In S. Clegg \& J. Bailey (Eds.), International Encyclopedia of Organization Studies (pp. 1152-1154). Thousand Oaks, CA: Sage. https://doi.org/10.4135/9781412956246.n392

Goetsch, D.L., \& Davis, S.B. (2006). Quality management. Introduction to Total Quality Management for Production, Processing, and Services, New Jersey: Prentice Hall.

Greenslade, J.H., \& Jimmieson, N.L. (2007). Distinguishing between task and contextual performance for nurses: development of a job performance scale. Journal of Advanced Nursing, 58(6), 602-611. https://doi.org/10.1111/j.1365-2648.2007.04256.x

Hair, J.F. (2014). Multivariate data analysis. Harlow, Essex: Pearson.

Helfrich, C.D., Li, Y., Mohr, D.C., Meterko, M., \& Sales, A.E. (2007). Assessing an organizational culture instrument based on the Competing Values Framework: Exploratory and confirmatory factor analyses. Implementation Science, 2(1), 2-13. https://doi.org/10.1186/1748-5908-2-13

Henri, J.F. (2006). Organizational culture and performance measurement systems. Accounting, Organizations and Society, 31(1), 77-103. https://doi.org/10.1016/j.aos.2004.10.003

Hochwälder, J., \& Brucefors, A.B. (2005). A psychometric assessment of a Swedish translation of Spreitzer's empowerment scale. Scandinavian Journal of Psychology, 46(6), 521-529. https://doi.org/10.1111/j.1467-9450.2005.00484.x

Hofstede, G. (2011). Dimensionalizing Cultures: The Hofstede model in context. Online Readings in Psychology and Culture, 2(1), 8. https://doi.org/10.9707/2307-0919.1014

Immordino, K.M. (2010). Organizational assessment and improvement in the public sector. Boca Raton: CRC Press.

Jabnoun, N., \& Sedrani, K. (2005). TQM, culture, and performance in UAE manufacturing firms. The Quality Management Journal, 12(4), 8-23. https://doi.org/10.1080/10686967.2005.11919267

Juran, J.M., \& Godfrey, A.B. (1999). Juran's quality handbook. New York: McGraw Hill.

Karimi, Y., \& Abdulkadir, S. (2012). The impact of organizational culture on the implementation of TQM: an empirical study in the Iranian oil company. American Journal of Industrial and Business Management, 2(4), 205-216. https://doi.org/10.4236/ajibm.2012.24027

Kaynak, H. (2003). The relationship between total quality management practices and their effects on firm performance. Journal of Operation Management, $\quad 21(4), \quad 405-435$. https://doi.org/10.1016/S0272-6963(03)00004-4

Kujala, J., \& Lillrank, P. (2004). Total quality management as a cultural phenomenon. The Quality Management Journal, 11(4), 43-55. https://doi.org/10.1080/10686967.2004.11919132

Li, J.H., Anderson, A.R., \& Harrison, R.T. (2003). Total quality management principles and practices in China. International Journal of Quality \& Reliability Management, 20(9), 1026-1050. https://doi.org/10.1108/02656710310500833

Linderman, K., Schroeder, R.G., Zaheer, S., \& Choo, A.S. (2003). Six Sigma: a goal-theoretic perspective. Journal of Operations Management, 21(2), 193-203. https://doi.org/10.1016/S0272-6963(02)00087-6

Metri, B.A. (2005). TQM critical success factors for construction firms. Management: Journal of Contemporary Management Issues, 10(2), 61-72.

Montes, L., Verdú Jover, A., \& Miguel Molina Fernández, L. (2003). Factors affecting the relationship between total quality management and organizational performance. International Journal of Quality \& Reliability Management, 20(2), 189-209. https://doi.org/10.1108/02656710310456617 
Morrill, C. (2008). Culture and organization theory. The ANNALS of the American Academy of Political and Social Science, 619(1), 15-40. https://doi.org/10.1177/0002716208320241

Naor, M., Goldstein, S.M., Linderman, K.W., \& Schroeder, R.G. (2008). The role of culture as driver of quality management and performance: infrastructure versus core quality practices. Decision Sciences, 39(4), 671-702. https://doi.org/10.1111/j.1540-5915.2008.00208.x

Nunnaly, J. (1978). Psychometric theory. New York: McGraw-Hill.

Powell, T.C. (1995). Total quality management as competitive advantage: a review and empirical study. Strategic Management Journal, 16(1), 15-37. https://doi.org/10.1002/smj.4250160105

Prajogo, D.I., \& Brown, A. (2004). The relationship between TQM practices and quality performance and the role of formal TQM programs: An Australian empirical study. The Quality Management Journal, 11(4), 31-42. https://doi.org/10.1080/10686967.2004.11919131

Prajogo, D.I., \& Mcdermott, C.M. (2005). The relationship between total quality management practices and organizational culture. International Journal of Operations \& Production Management, 25(11), 1101-1122. https://doi.org/10.1108/01443570510626916

Pride, W.M., \& Ferrell, O.C. (2006). Marketing Concepts and Strategies. Boston, MA: Houghton Mifflin Company.

Rahman, S.U., \& Bullock, P. (2005). Soft TQM, hard TQM, and organizational performance relationships: an empirical investigation. Omega, 33(1), 73-83. https://doi.org/10.1016/j.omega.2004.03.008

Sabella, A., Kashou, R., \& Omran, O. (2014). Quality management practices and their relationship to organizational performance. International of Operation \& Production Management, 34(12), 1487-1505. https://doi.org/10.1108/IJOPM-04-2013-0210

Sadikoglu, E., \& Olcay, H. (2014). The effects of total quality management practices on performance and the reasons of and the barriers to TQM practices in Turkey. Advances in Decision Sciences, 2014, 1-17. https://doi.org/10.1155/2014/537605

Sánchez-Rodríguez, C., \& Martínez-Lorente, Á.R. (2004). Quality management practices in the purchasing function. International Journal of Operations \& Production Management, 24(7), 666-687. https://doi.org/10.1108/01443570410541984

Shin, D., Kalinowski, J.G., \& El-Enein, G.A. (1998). Critical implementation issues in total quality management. SAM Advanced Management Journal, 63(1), 10.

Sila, I. (2007). Examining the effects of contextual factors on TQM and performance through the lens of organizational theories: An empirical study. Journal of Operations Management, 25(1), 83-109. https://doi.org/10.1016/j.jom.2006.02.003

Sohal, A.S., \& Terziovski, M. (2000). TQM in Australian manufacturing: factors critical to success. International Journal of Quality \& Reliability Management, 17(2), 158-168. https://doi.org/10.1108/02656710010304564

Soltani, E., Lai, P.C., \& Gharneh, N.S. (2005). Breaking through barriers to TQM effectiveness: Lack of commitment of upper-level management. Total Quality Management and Business Excellence, 16(8-9), 1009-1021. https://doi.org/10.1080/14783360500163201

Sousa-Poza, A., Nystrom, H., \& Wiebe, H. (2001). A cross-cultural study of the differing effects of corporate culture on TQM in three countries. International Journal of Quality \& Reliability Management, 18(7), 744-761. https://doi.org/10.1108/EUM0000000005778

Valmohammadi, C., \& Roshanzamir, S. (2015). The guidelines of improvement: Relations among organizational culture, TQM, and performance. International Journal of Production Economics, 164, 167-178. https://doi.org/10.1016/j.ijpe.2014.12.028

Wu, A.D., \& Zumbo, B.D. (2008). Understanding and using mediation and moderators. Social Indicators Research, 87(3), 367-392.

Yasin, M.M., Alavi, J., Kunt, M., \& Zimmerer, T.W. (2004). TQM practices in service organizations: an exploratory study into the implementation, outcome and effectiveness. Managing Service Quality: An International Journal, 14(5), 377-389.

$\mathrm{Zu}, \mathrm{X}$., Robbins, T., \& Fredendall, L. (2010). Mapping the critical links between organizational culture and TQM/Six Sigma practices. Int. J. Production Economics, 132, 86-106. 